\title{
Are multifunctional marine polysaccharides a myth or reality?
}

\author{
Svetlana Ermakova ${ }^{1 *}$, Mikhail Kusaykin ${ }^{1}$, Antonio Trincone ${ }^{2}$ and Zvyagintseva Tatiana ${ }^{1}$ \\ ${ }^{1}$ G.B. Elyakov Pacific Institute of Bioorganic Chemistry, Far Eastern Branch of the Russian Academy of Sciences, \\ Vladivostok, Russia, ${ }^{2}$ Istituto di Chimica Biomolecolare, Consiglio Nazionale delle Ricerche, Pozzuoli, Italy
}

Keywords: brown algae, polysaccharide, fucoidan, fucoidanase, food supplement, biological activities

OPEN ACCESS

Edited by:

Xuechen Li,

The University of Hong Kong,

Hong Kong

Reviewed by:

Paola Laurienzo,

Consiglio Nazionale delle Ricerche,

Italy

Yannis Karamanos

Université d'Artois, France

${ }^{\star}$ Correspondence

Svetlana Ermakova,

svetlana_ermakova@hotmail.com

Specialty section:

This article was submitted to

Chemical Biology

a section of the journal

Frontiers in Chemistry

Received: 30 April 2015

Accepted: 08 June 2015

Published: 30 June 2015

Citation:

Ermakova S, Kusaykin M, Trincone A and Tatiana $Z$ (2015) Are multifunctional marine

polysaccharides a myth or reality?

Front. Chem. 3:39.

doi: 10.3389/fchem.2015.00039
Marine algae are ancient photosynthetic organisms that constitute the largest group in the plant kingdom. They are used for functional food, cosmetic additives, supplements productions, and in traditional medicine due to taste, prophylactic, and therapeutic effects. Algae contain microelements and iodine-containing organic compounds, as well as vitamins, mannitol more than terrestrial plants.

Polysaccharides of algae are especially valuable substances. Some of them (for example agarose, carrageenans, and alginates) have found widespread application. Information about them was published a long time ago and described in detail in books. At the moment polysaccharides synthesized by brown algae (laminarans and especially fucoidans) are of greatest interest. A laminarans were found in both marine and terrestrial organisms. It should be noticed that fucoidans are truly marine polysaccharides. The general term "fucoidan" is used to integrate the molecules, differenced in composition, structure, and in degree of sulfation, acetylation, etc. (Berteau and Mulloy, 2003; Kusaykin et al., 2008). Content of fucoidans depends on the species and on the stage of development of algae and may vary from 0.1 to $20 \%$ of dry weight of algae (Mabeau et al., 1990; Zvyagintseva et al., 2003). Huge amount of reserves of fucoidans accumulate in brown algae, which grow in the seas at temperate and northern latitudes (Ermakova et al., 2011; Sokolova et al., 2011; Men'shova et al., 2012; Thinh et al., 2013). Analogs of these polysaccharides have not been found on the land till now. Fucoidans long since are attracted attention due to diverse biological activity, low toxicity, and plant origin (Berteau and Mulloy, 2003; Kusaykin et al., 2008). Last is important because of contamination and side effects of the preparation produced from animals (for example, heparin).

A large number of publications are devoted to the study of antitumor, anticoagulant, antimutagenic activities, and immunostimulatory, antiinfective and antioxidant properties of these polysaccharides. However, despite the obvious prospects for exploitation in medicine, none of fucoidan is declared yet as a drug. The reason is that the structural diversity of fucoidans is extremely large. Structural investigation of fucoidans is of great difficulties because of varieties of monosaccharide compositions, different types of glycosidic linkages, presence of large numbers of non-carbohydrate substituents. There are only a small number of fucoidans with established basic elements of the chemical structure (Chizhov et al., 1999; Bilan et al., 2002, 2004, 2008; Zvyagintseva et al., 2003; Shevchenko et al., 2007; Anastyuk et al., 2009, 2010, 2014; Kuznetsova, 2009; Ale et al., 2011; Vishchuk et al., 2011, 2013; Thinh et al., 2013). Unfortunately in the study of biological properties and enzymatic transformations of these molecules, fucoidans with unidentifiable structure are often used, thus reducing the generalization of the results obtained. Over the past 15-20 years there has been an increase in the number of structural studies of fucoidans. It became obvious that the study of their biological action, without regard to the structure does not allow to create drugs based on these polysaccharides.

It is now considered that fucoidans are species-specific polysaccharides. This means that each alga synthesizes fucoidan or set of fucoidans characteristic only for it. In monosaccharide composition of fucoidans necessarily there are sulfated residues of fucose and often galactose. 
As minor components residues of mannose, glucuronic acid, xylose, and other more rare monosaccharides, are present (Kusaykin et al., 2008).

1,3- $\alpha$-L-Fucans are most often found in algae (Zvyagintseva et al., 2003; Anastyuk et al., 2010). $\alpha$-1,4-Glycosidic linkage between L-fucose residues is less common and is present mainly as a 1,3;1,4- $\alpha$-L-fucans. Brown algae also often synthesize galactofucans. The position and content of galactose residues in various galactofucans depend on the type of algae; content is frequently comparable to the that of fucose (Shevchenko et al., 2007; Anastyuk et al., 2009; Thinh et al., 2013). This is the most structurally diverse group of fucoidans. A smallest group of fucoidans is represented by fucomannuronans (Imbs et al., 2011). Furthermore, there are fucoidans, containing more heterogeneous monosaccharide composition.

In order to establish the structure of polysaccharides the most promising approach is based on the use of enzymes. Enzymatic transformation of polysaccharides can be extremely useful not only for the establishment of structural features, but also for the access to biologically active fragments (Silchenko et al., 2013; Menshova et al., 2014; Trincone, 2014). Reports about producers and properties of the enzymes (fucoidanases) are rare despite the growing interest in the fucoidans (Kusaykin et al., 2008). No more than 20 producers of fucoidanases are known, mainly isolated from marine fungi and bacteria (Sakai et al., 2003; Descamps et al., 2006; Rodriguez-Jasso et al., 2010; Silchenko et al., 2013, 2014). This rareness is due to the absence of quantitative simple methods for determination of the activity of fucoidanases. Precise assessment of enzymatic features is also hampered by the use of structurally uncharacterized substrates. So, in their transformation enzymes with different specificities should be involved.

Few sources of fucoidanases were found among marine invertebrates (Kitamura et al., 1992; Giordano et al., 2006; Silchenko et al., 2014). Fucoidanase in Patinopecten yessoensis was discovered in 1992 by the action on fucoidan from Nemacystus decipiens (Kitamura et al., 1992). Information about the structure of substrate reported in the article, consisting of L-fucose residues and small amounts of D-galactose residues, is quite scarce. Data about the type of glycosidic linkages are absent (Tako et al., 1999). High molecular weight products (about $50 \mathrm{kDa}$ ) formed sufficiently under the action of fucoidanase from $P$. yessoensis. Information about their structures is not available.

We found new sources of fucoidanases: the vietnamese mollusk Lambis sp. and the marine bacteria Formosa algae KMM 3553 (Khanh et al., 2011; Silchenko et al., 2014). Analysis of the hydrolysis products of fucoidans with established structure from collection of our laboratory, showed that both fucoidanases are endo-enzymes hydrolyzing $\alpha$-1,4-glycosidic linkages in fucans (Silchenko et al., 2014).

Purification grade of fucoidans is also important for the investigation of biological properties. Unfortunately, uncharacterized crude preparations are often used even in scientific research. Methods for isolation and purification of fucoidan may be different. The most universal scheme includes preprocessing of algae by organic solvents extracting most secondary metabolites, such as polyphenols and other UV absorbing compounds (Shevchenko et al., 2005). These substances, usually powerful antioxidants, often are strongly associated with fucoidans and removal of them entails great difficulties. We show that the purification of fucoidans from impurities results in a loss of antioxidant activity (Imbs et al., 2015). Not only antioxidant, but also antibacterial activity of fucoidans can be completely or partially due to impurities. Separation of fucoidans from them is not always possible, as polysaccharides often form strong complexes with polyphenols, which cannot be destroyed without affecting the integrity of the fucoidan molecules. Nevertheless the evidence of antioxidant activity due to impurities of fucoidans were studied quite intensively (Wang et al., 2008; Hu et al., 2010; Costa et al., 2011). However the data on the purity of fucoidans is often absent.

It is interesting to note that specific biological activities of fucoidans are associated with their structures. So, the formation and growth of the colony of breast cancer cells are suppressed by galactofucans from Saccharina japonica and Undaria pinnatifida. Human colon cancer cells are more sensitive to fucoidan from Saccharina cichorioides (consisted of $(1 \rightarrow 3)$ $\alpha$-L-fucose residues), human melanoma cells-to fucoidan from Fucus evanescens (Moon et al., 2009; Vishchuk et al., 2011, 2013).

Thus, the intensification of structural studies of fucoidans and the use of highly purified preparations will help to dispel some myths about the effect of fucoidans on organisms and to outline the range of biological properties only related to polysaccharides. The first is immunomodulatory (Khil'chenko et al., 2011), antibacterial, antiviral (Prokofjeva et al., 2013), and antitumor activities (Ermakova et al., 2011; Vishchuk et al., 2011, 2013).

In Russia in 2006 the suplement "Fucolam ${ }^{\circledR}$ " (No 77.99.23.3.y.739.1.06, Russia), based on structurally characterized fucoidan from the brown alga Fucus evanescens, synthesizing from 12 to $15 \%$ of the polysaccharide, was registered. The biological effects of the "Fucolam ${ }^{\circledR}$ " are studied in detail. It was established that the "Fucolam ${ }^{\circledR}$ " in addition to the immunomodulatory, antibacterial, antiviral, and antitumoral activities has probiotic, hepatoprotective, glucose, and cholesterol lowering effects (Drozd et al., 2006, 2011; Kuznetsova, 2009; Khil'chenko et al., 2011; Lapikova et al., 2012; Besednova et al., 2014, 2015; Zaporozhets et al., 2014). It is a prominent representative of multifunctional agent and can serve as the base for drug development.

According to known data from the studies above mentioned, the spectrum of biological properties of fucoidans is wide enough. These natural substances are outstanding representatives of multifunctional compounds, and this is not a myth but a reality.

\section{Acknowledgments}

This work was supported by grants from REBR (14-04-93003, 15-04-01004_a) and Program of FEB RAS “P-42.” 


\section{References}

Ale, M. T., Mikkelsen, J. D., and Meyer, A. S. (2011). Important determinants for fucoidan bioactivity: a critical review of structure-function relations and extraction methods for fucose-containing sulfated polysaccharides from brown seaweeds. Mar. Drugs. 9, 2106-30. doi: 10.3390/md9102106

Anastyuk, S. D., Imbs, T. I., Dmitrenok, P. S., and Zvyagintseva, T. N. (2014). Rapid mass spectrometric analysis of a novel fucoidan, extracted from the brown alga Coccophora langsdorfii. ScientificWorldJournal. 2014:972450. doi: 10.1155/2014/972450

Anastyuk, S. D., Shevchenko, N. M., Nazarenko, E. L., Dmitrenok, P. S., and Zvyagintseva, T. N. (2009). Structural analysis of a fucoidan from the brown alga Fucus evanescens by MALDI-TOF and tandem ESI mass spectrometry. Carbohydr. Res. 344, 779-787. doi: 10.1016/j.carres.2009.01.023

Anastyuk, S. D., Shevchenko, N. M., Nazarenko, E. L., Imbs, T. I., Gorbach, V. I., Dmitrenok, P. S., et al. (2010). Structural analysis of a highly sulfated fucan from the brown alga Laminaria cichorioides by tandem MALDI and ESI mass spectrometry. Carbohydr. Res. 345, 2206-2212. doi: 10.1016/j.carres.2010.07.043

Berteau, O., and Mulloy, B. (2003). Sulfated fucans, fresh perspectives: structures, functions, and biological properties of sulfated fucans and an overview of enzymes active toward this class of polysaccharide. Glycobiology 13, 29R-40R. doi: $10.1093 /$ glycob/cwg058

Besednova, N. N., Zaporozhets, T. S., Kuznetsova, T. A., Kryzhanovskii, S. P., Kovalev, N. N., and Zviagintseva, T. N. (2014). Hepatoprotective effects of extracts and polysaccharides from seaweed. Antibiot. Khimioter. 59, 30-37.

Besednova, N. N., Zaporozhets, T. S., Somova, L. M., and Kuznetsova, T. A. (2015). Prospects for the use of extracts and polysaccharides from marine algae to prevent and treat the diseases caused by Helicobacter pylori. Helicobacter 20, 89-97. doi: 10.1111/hel.12177

Bilan, M. I., Grachev, A. A., Ustuzhanina, N. E., Shashkov, A. S., Nifantiev, N. E., and Usov, A. I. (2002). Structure of a fucoidan from the brown seaweed Fucus evanescens C. Ag. Carbohydr. Res. 337, 719-730. doi: 10.1016/S00086215(02)00053-8

Bilan, M. I., Grachev, A. A., Ustuzhanina, N. E., Shashkov, A. S., Nifantiev, N. E., and Usov, A. I. (2004). A highly regular fraction of a fucoidan from the brown seaweed Fucus distichus L. Carbohydr. Res. 339, 511-517. doi: 10.1016/j.carres.2003.10.028

Bilan, M. I., Vinogradova, E. V., Tsvetkova, E. A., Grachev, A. A., Shashkov, A. S., Nifantiev, N. E., et al. (2008). A sulfated glucuronofucan containing both fucofuranose and fucopyranose residues from the brown alga Chordaria flagelliformis. Carbohydr. Res. 343, 2605-2612. doi: 10.1016/j.carres.2008.06.001

Chizhov, A. O., Dell, A., Morris, H. R., Haslam, S. M., McDowell, R. A., Shashkov, A. S., et al. (1999). A study of fucoidan from the brown seaweed Chorda filum. Carbohydr. Res. 320, 108-219. doi: 10.1016/S0008-6215(99)00148-2

Costa, L. S., Fidelis, G. P., Telles, C. B., Dantas-Santos, N., Camara, R. B., Cordeiro, S. L., et al. (2011). Antioxidant and antiproliferative activities of heterofucans from the seaweed Sargassum filipendula. Mar. Drugs. 9, 952-966. doi: $10.3390 / \mathrm{md} 9060952$

Descamps, V., Colin, S., Lahaye, M., Jam, M., Richard, C., Potin, P., et al. (2006). Isolation and culture of a marine bacterium degrading the sulfated fucans from marine brown algae. Mar. Biotechnol. 8, 27-39. doi: 10.1007/s10126-005-5107-0

Drozd, N. N., Miftakhova, N. T., Savchik, E., Kalinina, T. B., Makarov, V. A., Imbs, T. I., et al. (2011). Antithrombotic and hemorrhagic activities of fucoidan isolated from Fucus evanescens brown algae. Eksp. Klin. Farmakol. 136, 471-473.

Drozd, N. N., Tolstenkov, A. S., Makarov, V. A., Kuznetsova, T. A., Besednova, N. N., Shevchenko, N. M., et al. (2006). Pharmacodynamic parameters of anticoagulants based on sulfated polysaccharides from marine algae. Bull. Exp. Biol. Med. 142, 591-593. doi: 10.1007/s10517-006-0426-3

Ermakova, S., Sokolova, R., Kim, S. M., Um, B. H., Isakov, V., and Zvyagintseva, T. (2011). Fucoidans from brown seaweeds Sargassum hornery, Eclonia cava, Costaria costata: structural characteristics and anticancer activity. Appl. Biochem. Biotechnol. 164, 841-850. doi: 10.1007/s12010-011-9178-2

Giordano, A., Andreotti, G., Tramice, A., and Trincone, A. (2006). Marine glycosyl hydrolases in the hydrolysis and synthesis of oligosaccharides. Biotechnol. J. 1, 511-530. doi: 10.1002/biot.200500036
Hu, T., Liu, D., Chen, Y., Wu, J., and Wang, S. (2010). Antioxidant activity of sulfated polysaccharide fractions extracted from Undaria pinnitafida in vitro. Int. J. Biol. Macromol. 46, 193-198. doi: 10.1016/j.ijbiomac.2009.12.004

Imbs, T. I., Shevchenko, N. M., Semenova, T. L., Sukhoverkhov, S. V., and Zvyagintseva, T. N. (2011). Compositional heterogeneity of sulfated polysaccharides synthesized by the brown alga Costaria costata. Chem. Nat. Comp. 47, 96-97. doi: 10.1007/s10600-011-9839-y

Imbs, T. I., Skriptsova, A. V., and Zvyagintseva, T. N. (2015). Antioxidant activity of fucose-containing sulfated polysaccharide obtained from Fucus evanescens using different extraction methods. J. Appl. Phycol. 27, 545-553. doi: 10.1007/s10811-014-0293-7

Khanh, H. H. N., Kusaykin, M., Zakharenko, A., Ly, B. M., Hang, C. T. T., Ngoc, N. T. D., et al. (2011). Tinh sach va khao sat dac tinh cua enzyme thuy phan alginate tu gan tuy oc ban tay Lambis sp. (Purification and properties of an alginate lyase from the hepatopancreas of Lambis sp.). J. Biotechnol. 9, 1-9.

Khil'chenko, S. R., Zaporozhets, T. S., Shevchenko, N. M., Zvyagintseva, T. N., Vogel, U., Seeberger, P., et al. (2011). Immunostimulatory activity of fucoidan from the brown alga Fucus evanescens: role of sulfates and acetates. J. Carbohydr. Chem. 30, 291-305. doi: 10.1080/07328303.2011.604456

Kitamura, K., Masaru, M., and Yasui, T. (1992). Enzymic degradation of fucoidan by fucoidanase from the hepatopancreas of Patinopecten yessoensis. Biosci. Biotechnol. Biochem. 56, 490-494. doi: 10.1271/bbb.56.490

Kusaykin, M., Bakunina, I., Sova, V., Ermakova, S., Kuznetsova, T., Besednova, N., et al. (2008). Structure, biological activity, and enzymatic transformation of fucoidans from the brown seaweeds. Biotechnol. J. 3, 904-915. doi: 10.1002/biot.200700054

Kuznetsova, T. A. (2009). Fucoidan extracted from Fucus evanescens brown algae corrects immunity and hemostasis disorders in experimental endotoxemia. Bull. Exp. Biol. Med. 147, 66-69. doi: 10.1007/s10517-009-0445-y

Lapikova, E. S., Drozd, N. N., Makarov, V. A., Zviagintseva, T. N., Shevchenko, N. M., Kuznetsova, T. A., et al. (2012). Influence of intravenous injection of fucoidan from brown seaweed Fucus evanescens by plasma rabbits anticoagulant activity and neutralisation by sulphate protamin of fucoidans antithrombin activity in vitro. Patol. Fiziol. Eksp. Ter. 2, 42-44.

Mabeau, S., Kloareg, B., and Joseleau, J. P. (1990). Fractionation and analysis of fucans from brown algae. Phytochemistry 29, 2441-2445. doi: 10.1016/00319422(90)85163-A

Menshova, R. V., Ermakova, S. P., Anasyuk, S. D., Isakov, V. V., Dubrovskaya, Y. V., Kusaikin, M. I., et al. (2014). Structure, enzymatic transformation and anticancer activity of branched high molecular weight laminaran from brown alga Eisenia bicyclis. Carbohydr. Polym. 99, 101-109. doi: 10.1016/j.carbpol.2013.08.037

Men'shova, R. V., Ermakova, S. P., Rachidi, S. M., Al-Hajje, A. H., Zvyagintseva, T. N., and Kanaan, H. M. (2012). Seasonal variations of the composition, structural features, and antitumor properties of polysaccharides from Padina pavonica (Lebanon) as a function of composition. Chem. Nat. Comp. 47, 870-875. doi: 10.1007/s10600-012-0091-x

Moon, H. J., Lee, S. H., Ku, M. J., Yu, B. C., Jeon, M. J., Jeong, S. H., et al. (2009). Fucoidan inhibits UVB-induced MMP-1 promoter expression and down regulation of type I procollagen synthesis in human skin fibroblasts. Eur. J. Dermatol. 19, 129-134. doi: 10.1684/ejd.2008.0611

Prokofjeva, M. M., Imbs, T. I., Shevchenko, N. M., Spirin, P. V., Horn, S., Fehse, B., et al. (2013). Fucoidans as potential inhibitors of HIV-1. Mar. Drugs. 11, 3000-3014. doi: 10.3390/md11083000

Rodriguez-Jasso, R. M., Mussatto, S. I., Pastrana, L., Aguilar, C. N., and Teixeira, J. A. (2010). Fucoidan-degrading fungal strains: screening, morphometric evaluation, and influence of medium composition. Appl. Biochem. Biotechnol. 162, 2177-2188. doi: 10.1007/s12010-010-8992-2

Sakai, T., Ishizuka, K., and Kato, I. (2003). Isolation and characterization of a fucoidan-degrading marine bacterium. Mar. Biotechnol. 5, 409-416. doi: 10.1007/s10126-002-0118-6

Shevchenko, N. M., Anastiuk, S. D., Gerasimenko, N. I., Dmitrenok, P. S., Isakov, V. V., and Zviagintseva, T. N. (2007). Polysaccharide and lipid composition of the brown seaweed Laminaria gurjanovae. Russ. J. Bioorganic Chem. 3, 96-107. doi: 10.1134/s1068162007010116

Shevchenko, N. M., Imbs, T. I., Urvantseva, A. I., Kusaykin, M. I., Kornienko, V. G., Zvyagintseva, T. N., et al. (2005). Method of Processing Seaweed. European Patent No. WO2005/014657. 
Silchenko, A. S., Kusaykin, M. I., Kurilenko, V. V., Zakharenko, A. M., Isakov, V. V., Zaporozhets, T. S., et al. (2013). Hydrolysis of fucoidan by fucoidanase isolated from the marine bacterium Formosa algae. Mar. Drugs. 11, 2413-2430. doi: $10.3390 / \mathrm{md} 11072413$

Silchenko, A. S., Kusaykin, M. I., Zakharenko, A. M., Menshova, R. V., Khanh, H. H. N., Dmitrenok, P. S., et al. (2014). Endo-1,4-fucoidanase from Vietnamese marine mollusk Lambis sp. which producing sulphated fucooligosaccharides. J. Mol. Cat. B Enzym. 102, 154-160. doi: 10.1016/j.molcatb.2014.02.007

Sokolova, R. V., Ermakova, S. P., Awada, S. M., Zvyagintseva, T. N., and Kanaan, H. M. (2011). Composition, structural characteristics, and antitumor properties of polysaccharides from the brown algae Dictyopteris polypodioides and Sargassum sp. Chem. Nat. Compd. 47, 329-334. doi: 10.1007/s10600-011-9925-1

Tako, M., Nakada, T., and Hongou, F. (1999). Chemical characterization of fucoidan from commercially cultured Nemacystus decipiens (Itomozuku). Biosci. Biotechnol. Biochem. 63, 1813-1815. doi: 10.1271/bbb.63.1813

Thinh, P. D., Menshova, R. V., Ermakova, S. P., Anastyuk, S. D., Ly, B. M., and Zvyagintseva, T. N. (2013). Structural characteristics and anticancer activity of fucoidan from the brown alga Sargassum mcclurei. Mar. Drugs 11, 1456-1476. doi: $10.3390 / \mathrm{md} 11051456$

Trincone, A. (2014). Molecular fishing: marine oligosaccharides. Front. Mar. Sci. 1:26. doi: $10.3389 /$ fmars. 2014.00026

Vishchuk, O. S., Ermakova, S. P., and Zvyagintseva, T. N. (2011). Sulfated polysaccharides from brown seaweeds Saccharina japonica and Undaria pinnatifida: isolation, structural characteristics, and antitumor activity. Carbohydr. Res. 346, 2769-2776. doi: 10.1016/j.carres.2011.09.034

Vishchuk, O. S., Ermakova, S. P., and Zvyagintseva, T. N. (2013). The effect of sulfated $(1 \rightarrow 3)$-alpha-l-fucan from the brown alga Saccharina cichorioides
Miyabe on resveratrol-induced apoptosis in colon carcinoma cells. Mar. Drugs. 11, 194-212. doi: 10.3390/md11010194

Wang, J., Zhang, Q., Zhang, Z., and Li, Z. (2008). Antioxidant activity of sulfated polysaccharide fractions extracted from Laminaria japonica. Int. J. Biol. Macromol. 42, 127-132. doi: 10.1016/j.ijbiomac.2007. 10.003

Zaporozhets, T. S., Besednova, N. N., Kuznetsova, T. A., Zviagintseva, T. N., Makarenkova, I. D., Kryzhanovskii, S. P., et al. (2014). The prebiotic potential of polysaccharides and extracts of seaweeds. Russ. J. Mar. Biol. 40, 1-9. doi: $10.1134 /$ S1063074014010106

Zvyagintseva, T. N., Shevchenko, N. M., Chizhov, A. O., Krupnova, T. N., Sundukova, E. V., and Isakov, V. V. (2003). Water-soluble polysaccharides of some far-eastern brown seaweeds. Distribution, structure, and their dependence on the developmental conditions. J. Exp. Mar. Biol. Ecol. 294, 1-13. doi: $10.1016 /$ S0022-0981(03)00244-2

Conflict of Interest Statement: The authors declare that the research was conducted in the absence of any commercial or financial relationships that could be construed as a potential conflict of interest.

Copyright (๑ 2015 Ermakova, Kusaykin, Trincone and Tatiana. This is an openaccess article distributed under the terms of the Creative Commons Attribution License (CC BY). The use, distribution or reproduction in other forums is permitted, provided the original author(s) or licensor are credited and that the original publication in this journal is cited, in accordance with accepted academic practice. No use, distribution or reproduction is permitted which does not comply with these terms. 